\title{
Reading and Writing Skills Development for kindergarten Children with Learning Disabilities Using Artificial Intelligence Applications
}

\author{
Submitted by \\ Weal Ahmed Abdelfattah Mohammed Ahmed
}

A Research for Fulfilling Requirements of Ph.D. Degree in Education

(Kindergarten)

\section{Supervisory Panel}

\section{Prof. Atef Adli Fahmi}

Professor of Child Education

Dean of Faculty of Education

for Early Childhood

Cairo University

\section{Dr. Mona Mohammed Abdullah}

Lecturer at Department of Educational Sciences

Faculty of Education for Early Childhood

Cairo University 


\begin{abstract}
:
The research entitled " Reading and Writing Skills Development for kindergarten Children with Learning Disabilities Using Artificial Intelligence Applications" has aimed at using artificial intelligence applications to develop reading and writing skills for kindergarten children with developmental learning disabilities. The sample was (40) children with learning disabilities from kindergarten stage (KG 2) their ages (5-6) years old. The researcher has used the experimental methodology with two groups (control and experimental) for around four weeks. The results showed the effect of using artificial intelligence applications to develop reading and writing skills for kindergarten children with developmental learning disabilities.
\end{abstract}

Key words: Artificial Intelligence, Reading and Writing skills and Developmental Learning Disabilities.

\title{
مستخلص البحث
}

در اسة بعنوان "تنمية مهار ات القراءة والكتابة لدى أطفال الروضة من ذوي صعوبات التعلم باستخدام تطبيقات الذكاء الاصطناعي" وتهدف الدراسة إلى استخدام تطبيقات الذكاء الاصطناعي لتنمية مهار ات القر اعة و الكتابة لاى أطفال رياض الأطفال ذوي صعوبات التعلم النمائية. وكانت العينة مكونة من ( • ع) أطفال من ذوي صعوبات التعلم من مرحلة رياض الأطفال (KG 2)، وكان أعمار الأطفال من (_- (7) سنوات. واستخدم الباحث المنهج التجريبي بمجموعتين (ضابطة وتجريبية) لمدة أربعة أسابيع تقريباً. وأظهرت النتائج فاعلية استخدام تطبيقات الذكاء الاصطناعي في تتمية مهارات القراءة والكتابة لدى أطفال رياض الأطفال ذوي صعوبات التعلم النمائية. الكلمات المفتاحية: الذكاء الاصطناعي، مهار ات القر اءة والكتابة، صعوبات التعلم النمائية. 


\section{Introduction:}

In the age of globalization and internet, artificial intelligence applications have become necessary, especially as being a demand for Egyptian education system which needs to be transformed from a traditional system to a technology based-environment. In the Egyptian context, English is considered a foreign language to be acquired. The children with learning disabilities cannot be rehabilitated in the regular class they need irregular solutions such as artificial intelligence learning applications.

The potential application of artificial intelligence in kindergarten children's education is investigated in this research. This research briefly introduces the critical technologies of artificial intelligence and their relationship to kindergarten children's learning, and discusses the possible applications of artificial intelligence in kindergarten children's learning.

\section{Literature review}

Artificial intelligence applications enable children with learning disabilities to learn reading and writing skills and to have a basic role in interaction with the learning process. These applications attract the children attentions enabling them to be more focused on learning reading and writing skills.

\section{Research Questions}

The researcher was trying to provide answers to the following questions to achieve the objectives of the research:

1-What are the required skills of reading and writing for kindergarten children with learning disabilities?

2-What is the effect of using artificial intelligence applications on reading and writing development for kindergarten children with learning disabilities? 


\section{Importance of the research:}

- This research has focused on the importance of using artificial intelligence applications.

- Reading and writing skills development for kindergarten children with developmental learning disabilities.

- Displaying the vital role of kindergarten teachers in reading and writing skills development as for kindergarten children with developmental learning disabilities.

\section{Research terms:}

\section{Children with Developmental learning disabilities:}

A learning disability, according to the individuals with disabilities Act (IDEA), is a disorder in one or more of the basic cognitive abilities involved in understanding or using spoken or written language (Adebisi, Rufus Olanrewaju \& et al: 2015, 15).

The term 'learning disabilities' is used to describe the most common types of specific learning disabilities like dyslexia, dysphasia, dysgraphia, dyspraxia, and dyscalculia. (Ouherrou, N., Elhammoumi, O., Benmarrakchi, F., \& El Kafi, J.: 2019, 1778).

\section{Artificial Intelligence:}

Artificial intelligence is as a computer system with the ability to perform tasks commonly related to intelligent beings. Artificial intelligence is a machine which thinks, diagnoses, understands languages and solves problems (Tuomi, I.:2018, 7). 


\section{Purpose of the research:}

The research main Purpose is using artificial intelligence applications on development of English language reading and writing for kindergarten children with learning disabilities.

The researcher has explained the required skills of reading and writing for kindergarten children with learning disabilities and the importance of using artificial intelligence programs to develop children with learning disabilities in addition to the role of artificial intelligence applications in learning children with learning disabilities showing the natural language Processing. The researcher has pointed out to the role of kindergarten teachers during using the existing artificial intelligence applications for kindergarten children with developmental learning disabilities.

\section{1-The required skills of reading and writing for kindergarten children with learning disabilities:}

According to the "world Health Organization" (WHO), there are three general learning functions, which are reading, writing and mathematics:

a. Reading disabilities: there are difficulties of recognizing letters and words, in addition to poorer fluency, understanding words and the capacity of breaking up words into sounds.

b. Written expression difficulties: including handwriting, spelling, composition of words and organization of ideas.

c. Mathematics disabilities: including difficulties in learning math concepts, organize numbers and remember math facts. (Taouil, M., Begdouri, A., \& Majda, A.: 2018, 426).

The main learning disabilities types for children at the kindergarten age are: 
1) The Memory: Represent the ability of remembering of something or fact that had been told before.

2) The Concentration: child ability of concentrating on one mission at a time and forget about any other idea or thought.

3) The Attention: means the attention the child has one aspect from the surrounding environment for children at school stage the learning disabilities may include:

a) Dyslexia: represents the awkwardness of comprehension the written words.

b) Dysgraphia: referring to the difficulty of writing in a specific space.

c) Dyscalcus: means the difficulty of performing mathematical calculation (Majed, R, Hatem, H \& Naser, A: 2020, 23).

Children's reading disabilities include four basic forms related to alphabet recognition, word recognition, fluency and spontaneity, and reading

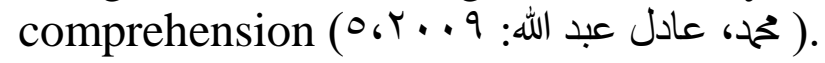

Dyslexia has been associated for many years with the phenomenon of letter-flipping when children read or write a word. While dyslexia is often behind the child's inability to link sounds to symbols when analyzing a word, which is called decoding, meaning that sounds are linked to the shape of letters

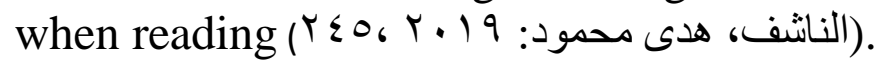

Children with dyslexia show poor reading comprehension because they are inaccurate and/or they have slow decoding skills. Children with hyperlexia have poor reading comprehension because of their cognitive and language deficiencies. Children with language learning disabilities have deficits in word recognition and listening comprehension (Kamhi, A. G., \& Catts, H. W.:2002, $58)$.

Among the writing skills needed for children with learning difficulties are to develop their ability to distinguish directions, draw horizontal, vertical, 
curved and perpendicular lines, write words, and write letters زهران، حامد عبد)

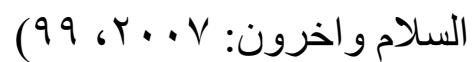

Many children with learning disabilities are deficient in writing tasks such as spelling, punctuation and word usage. Some problems contribute to handwriting difficulties such as motor problems, faulty visual memory, poor instruction, emotional problems, and lack of motivation. Fine motor problems can interfere with handwriting. For example, a child might know how to spell a word, but he cannot write the spelling. There are handwriting problems such as slowness, messiness, inability to stay on a horizontal line, illegible letters, too much or too little pencil pressure, incorrect direction of letters and numbers, too much or too little slant, shaping problems (letters too oral or too in shape), and mirror writing. These children do not have the right idea of the size of letters during writing. The size of the letters might be too large or too small. (Halilu, M., \& Ahmed, S.: 2020, 5)

The following studies have consistently indicated that using artificial intelligence applications to develop the reading and writing skills for kindergarten children with learning disabilities on the reading and writing skills.

A study of Haidan Lu, Kaili Zhang and Qiaoyun Liu (2020). The study entitled "Reading fluency and pitch discrimination abilities in children with learning disabilities". The study examined pitch perception and pitch matching tasks in children with learning disabilities to determine if there was any connection between the reading fluency and these tests. The methods of the study used different kinds of pitch reading fluency tests and discrimination tests to compare the two groups. The results show that the accuracy of pitch reading fluency and discrimination was significantly different in these children with learning disabilities relative to developing children. Also the results show that they exhibit impaired pitch matching, which linked to reading skills. 
The study of Bonneton-Botté, N., Fleury, S., Girard, N., Le Magadou, M., Cherbonnier, A., Renault, M. \& Jamet, E. (2020). The entitled:" Can tablet apps support the learning of handwriting? An investigation of learning outcomes in kindergarten classroom". The aim of the study was to assess the impact of implementing a digital notebook application designed for a stylus-oriented tablet in kindergarten classrooms. The exercises were personalized on a sample of (22) kindergarten classes participated in a (12) week teacher-implemented program, half working exclusively with paper and pencil, and half partially undertaking their handwriting training with the digital notebook. A paper-and-pen writing task was administered as a pre-test and post-test to assess the progress of all the children. Data analysis showed that learning outcomes with the digital notebook were contingent upon the children's initial handwriting level, as the benefits of training with the application were demonstrated only for children with a medium level at the start of the study.

In addition the study of Bissaco, M. A. S., Frere, A. F., Bissaco, L. F., Manrique, A. L., Dirani, E., Rugerro, N., \& Amate, F. C. (2020). The study entitled: "A computerized tool to assess reading skills of students with motor impairment". This study presents computerized test. A conventional card-based test was also used. Both tests were performed by (33) preschool children without mobility impairment all aged between (4) years and six months and (6) years and two months. The Wilcoxon signed-rank test was used and the children's ttest was conducted. Additionally, (7) volunteers with moderate mobility impairment (group T), aged between (8) and (17) years old accompanied by two physical therapists, took the computerized test using the adapted peripheral device and performed the required tasks without difficulty and without showing signs of fatigue. The results showed that the computerized test may enable teachers to include children with mobility difficulties in literacy assessments and to design new teaching strategies that are suitable for their levels. 


\section{2-The importance of Using Artificial Intelligence Programs to develop Children with Learning Disabilities:}

Technology plays an important role in children everyday lives. However, studies also have showed that there are different perceptions regarding the advantages and disadvantages of the utilizing digital technology for children, particularly during their early ages of development (Gjelaj, M., Buza, K., Shatri, K., \& Zabeli, N.: 2020, 166).

The utilizing of technology represents many children with disabilities that required tools to be more successful in learning. The decision to select the types of technology that would match the needs of children with learning disabilities poses various questions on its utilizing (Adebisi, Rufus Olanrewaju \& et al: $2015,15)$.

It is possible to predict dyslexia and dyspraxia banked on simple tasks by utilizing Machine Learning technologies. It was proved that trained Machine Learning -based predictors can accurate better than human. Using machine learning is used to help children with learning disabilities. Accuracy can be improved by collecting more data. Machine learning algorithms, and deep learning, could be utilized for processing pictures and audio data with minimal pre-processing without needing manual analysis. On the other hand, dysgraphia can be detected on just drawing. If we can do that, this will enable a screening for dysgraphia available for children under the age of writing (Richard, G., \& Serrurier, M.: 2020, 11).

Adebisi, R. O. \& et al. (2015) have a study entitled "Efficacy of assistive technology on the educational programme of children with learning disabilities in inclusive classrooms of Plateau State Nigeria". The purpose of this research was to find out how assistive technology can be effectively used as part of the 
educational programs of children with learning disabilities in an inclusive classroom setting-by investigating the teachers' perceptions regarding the use of assistive technology. Utilizing a cross-sectional survey, the sample had the teachers of the children with learning disabilities from three selected schools which consisted (40) children. The result revealed that assistive technology can be used to improve the educational program of children with learning disabilities. It also revealed that bond exited between assistive technology and inclusive education as regards to children with learning disabilities.

\section{3-The Role of Artificial Intelligence Applications in Learning Children with Learning Disabilities:}

Assistive technology is any device that assists a child with a disability and utilized to improve the functioning of a child with a disability (Adebisi, Rufus Olanrewaju \& et al: 2015, 16).

Mobile applications are a resource which can be utilized in different sectors to facilitate them. Nowadays, it is common to see children using Smartphones and using mobile applications. So, applications are an integral part in the experience of having access to the stored information in smartphones (Mendoza Chavarria, V. C.: 2019, 34).

The Educational App Store, has determined many mobile applications that are very necessary in learning, especially learning English language skills (Mendoza Chavarria, V. C.: 2019, .35).

There has been an increasing interest to carry over the success stories of machine learning in different domains such as dyslexia and dysgraphia from two sides:

A. writing: a picture of handwritten text for motor dysgraphia.

B. reading: a relatively little figure of audio recordings for dyslexia (Richard, G., \& Serrurier, M.: 2020, 2). 
The integration of educational technology in early childhood education is necessary. This creates the need to study application of resources and methodologies that match kindergarten children. Artificial intelligence approaches have been incorporated to educational technology resources providing improved interaction to kindergarten children (Prentzas, J.: 2013, 169).

Artificial intelligent teaching robot mixes multi-disciplinary human knowledge through machine learning, and mixes advanced technologies. Educational robots will add new interest to children's learning activities. In the process of teaching, artificial intelligent teaching robots can be like teaching aids. During the communication and interaction with children, artificial intelligent educational robot searches answers on the internet and self-learns (Jin, L.: 2019, 5)

Artificial intelligent teaching system is an adaptive teaching and learning system, that changes the traditional transmission of knowledge between educators and children. Compared with the traditional classroom teaching, the teaching results of artificial intelligent teaching are improved. Artificial intelligent teaching system supports individualized learning, learning resources and learning companions to support children reaching the goals. In the process of interaction with children, the artificial intelligent teaching system utilizes huge data analysis regarding to the children's information such as facial expression response, knowledge feedback and speech expression (Jin, L.: 2019, $4)$.

\section{4-The Natural Language Processing:}

Natural language processing is important to artificial intelligence because it focuses on the interactions between computers and human languages, especially, how to program computers to analyze natural language data (Jin, L.: 2019, 2). 
Natural Language Understanding is the ability of a machine to understand humans by their languages. A computer is adept at dealing with structured rather than unstructured data. A human languages are governed by grammar (Pathak, N.: 2017, 12).

\section{5-The Role of Kindergarten Teachers:}

Teachers no longer just spend the classroom time to pass on knowledge. Nowadays, the role of a teacher is the supporter of children's construction of knowledge. The necessary formation should be by watching, listening to videos or reading e-books out of classes (Xu, Ziling \& Shi, Yeli: 2018, 880).

Some of absent children loved the learning technique and others could rewatched the teaching videos, so the teachers can record all their lectures beyond the kindergarten then send them online (Purbani, Widyastuti \& Taufik: 2020, 154).

Teacher should analyze which technology will be effective during learning. During the learning process, teacher should consider many factors like which media can be selected to play the video, if it supplies mobile technology or not, the volumn and quality of video (Yildirim, F. S., \& Kiray, S. A.: 2016, $4)$.

Teacher should expect each video prepared for children. Teacher should expect children know the things they learn, transfer and adapt their information in the scope of the video they watch (Yildirim, F. S., \& Kiray, S. A.: 2016, 4).

The learning of the English language for children becomes a challenge. The teacher will play a vital role in the teaching process and in motivating the child to learn and understand (Mendoza Chavarria, V. C.: 2019, 51).

\section{6- The Existing Artificial Intelligence Applications for Kindergarten Children with Developmental Learning Disabilities:}


The computer is not the only device through which languages can be acquired. Mobile devices such as smartphones and iPads are now common. Many tools are used to enhance children' learning. Applications such as Facebook, Twitter, and messaging forums are used to allow children to participate in a greater learning community (Webb, M., \& Doman, E.: 2016, 45).

"Variable Speech Control" is a tool in form of tape recorder that enables the child to play the texts recorded in audio tape very fast than the originally recorded. This is very useful for children who better understand when texts are presented at a slow average (Adebisi, Rufus Olanrewaju \& et al: 2015, 17).

There is an application called "Dyslexia Baca" is a mobile application providing a learning tool for children suffering from dyslexia. "Dyslexia Baca" is designed and implemented by solving the problems of difficulties which faced by dyslexic children in recognizing and memorizing the letters. "Dyslexia Baca" motivates children to read by recognizing the letters and training recalling the learned information. Dyslexia Baca provides visual graphics for confusing letters like p, q, b, d, m, and w. in addition to a series of games (Rajapakse, S., Polwattage, D., Guruge, U., Jayathilaka, I., Edirisinghe, T., \& Thelijjagoda, S.: 2018,2)

Another application called "Dyslexia Friendly Reader" application. It is focused on overcoming the limitations of existing reading applications and present a prototype with significant features (Rajapakse, S., \& et al: 2018, 3)

The study of Khan, R. U., Cheng, J. L. A., \& Bee, O. Y. (2018). Entitled: "Machine Learning and Dyslexia: Diagnostic and Classification System (DCS) for Kids with Learning Disabilities". The study aimed to use an automated diagnostic and classification system. The system is trained by pre-classified data of (857) school children scores in spelling and reading. The system has three components: the diagnostic module, classification, an analysis tool. The results 
were $(23 \%)$ of children were at risk for dyslexia in the training data and (20.7\%) in the testing data with $(98 \%)$ of accuracy.

\section{Procedures:}

\section{Research Hypotheses:}

1- There are statistically significant differences between the mean of the experimental group children's scores and the mean of the control group children's scores in the post-test of using artificial intelligence applications to develop reading and writing skills for kindergarten children with learning disabilities in the direction of the experimental group.

2- There are statistically significant differences between the mean levels of children's grades in the pre and post scales that were given after using artificial intelligence applications to develop reading and writing skills for kindergarten children with learning disabilities in the direction of the post scale.

3- There are statistically significant differences between the mean levels of children's grades in the pre and post scales that were given after using artificial intelligence applications to develop reading and writing skills for kindergarten children with learning disabilities on the reading and writing skills scale in English language in the direction of the follow-up scale.

\section{Research sample:}

This study was carried out in "Zewel kindergarten" in Mansoura city. It has targeted only reading and writing skills of English as a foreign language using the artificial intelligence applications. The sample included (40) children with learning disabilities.

\section{Research method:}


A quantitative research method was utilized in this study. In an experimental design, KG2 children completed a reading and writing pre-test, a treatment and then a reading and writing post-test.

\section{Research tools:}

1- Reading and writing scale (Prepared by the researcher).

2- Artificial intelligence applications to develop reading and writing skills for kindergarten children with learning disabilities.

\section{Homogeneity of the sample:}

The researcher has found homogeneity between the average grade levels of kindergarten children in terms of time and intelligence using the chi-square test as shown in table (1).

\section{Table (1)}

The indicates of differences between the average grades of kindergarten children in age and intelligence

$$
\mathrm{N}=20
$$

\begin{tabular}{|c|c|c|c|c|c|}
\hline \multirow[t]{2}{*}{ Variables } & \multirow{2}{*}{$\begin{array}{l}\text { chi- } \\
\text { square }\end{array}$} & \multirow[t]{2}{*}{ Sig. level } & \multirow{2}{*}{$\begin{array}{l}\text { Degrees } \\
\text { of } \\
\text { freedom }\end{array}$} & \multicolumn{2}{|c|}{ Sig. limits } \\
\hline & & & & 0.001 & 0.05 \\
\hline Chronological Age) & 3.5 & Not sig. & 4 & 13.3 & 9.5 \\
\hline Intelligence & 4 & Not Sig. & 7 & 18.5 & 14.1 \\
\hline
\end{tabular}

It is clear from table (1) that there are no statistically significant differences between the average grades of kindergarten children in age and intelligence, which indicates the homogeneity of these children.

The researcher has found homogeneity between the average grade levels of kindergarten children in reading and writing skills as shown in table (2). 


\section{Table (2)}

Homogeneity between the average grade levels of kindergarten children in reading\& writing skills

$$
\mathrm{N}=20
$$

\begin{tabular}{|c|c|c|c|c|c|}
\hline \multirow[t]{2}{*}{ Variables } & \multirow{2}{*}{$\begin{array}{l}\text { chi- } \\
\text { square }\end{array}$} & \multirow[t]{2}{*}{ Sig. level } & \multirow{2}{*}{$\begin{array}{l}\text { Degrees } \\
\text { of } \\
\text { freedom }\end{array}$} & \multicolumn{2}{|c|}{ Sig. limits } \\
\hline & & & & 0.001 & 0.05 \\
\hline Reading & 10 & Not sig. & 9 & 21.7 & 16.9 \\
\hline Writing & 1.2 & Not Sig. & 3 & 11.3 & 7.8 \\
\hline
\end{tabular}

It is clear from table (2) that there are no statistically significant differences between the average grades of kindergarten children in reading and writing skills in the English language, which indicates the homogeneity of these children.

Parity between the children of the experimental and control groups in age and intelligence

The researcher found an indication of the differences between the children's scores means in the experimental and control groups in the pre-test scale in chronological age and intelligence as shown in table (3). 
Table (3)

Parity between the children of the experimental and control groups in the age and intelligence

$$
\mathrm{N}=40
$$

\begin{tabular}{|c|c|c|c|c|c|c||}
\hline \multirow{2}{*}{ Variables } & \multicolumn{2}{|c|}{$\begin{array}{c}\text { experimental group } \\
\mathbf{N = 2 0}\end{array}$} & \multicolumn{2}{c|}{$\begin{array}{c}\text { control group } \\
\mathbf{N = 2 0}\end{array}$} & \multirow{T}{*}{ Sig. level } \\
\cline { 2 - 7 } & Mean 1 & $\begin{array}{c}\text { standard } \\
\text { deviation1 }\end{array}$ & Mean2 & $\begin{array}{c}\text { standard } \\
\text { deviation2 }\end{array}$ & & \\
\hline Chronological age & 58,52 & 12.76 & 61.38 & 0.92 & 1.032 & Not sig. \\
\hline Intelligence & 98.94 & 2.96 & 97.52 & 3.55 & 1.414 & Not Sig. \\
\hline
\end{tabular}

$\mathrm{T}=2.42$ level 0,01

$\mathrm{T}=1,68$ level 0,05

It is clear from table (3) that there are no statistically significant differences between the means of the children's scores of the experimental and control groups in the pre-test scale in chronological age and intelligence, which indicates the equivalence of the two groups.

\section{Parity between the experimental and control group children in reading and writing skills}

The researcher has found an indication of the differences between the mean of the children's scores of the experimental and control groups in the pretest scale in Reading\& writing skills as shown in table (4) 


\section{Table (4)}

Parity between the children of the experimental and control groups in reading and writing skills

$$
\mathbf{N}=\mathbf{4 0}
$$

\begin{tabular}{|c|c|c|c|c|c|c||}
\hline \multirow{2}{*}{ Variables } & \multicolumn{2}{|c|}{$\begin{array}{c}\text { experimental group } \\
\mathbf{N = 2 0}\end{array}$} & \multicolumn{2}{c|}{$\begin{array}{c}\text { control group } \\
\text { N=20 }\end{array}$} & T & \multirow{2}{*}{ Sig. level } \\
\cline { 2 - 8 } & Mean 1 & $\begin{array}{c}\text { standard } \\
\text { deviation1 }\end{array}$ & Mean2 & $\begin{array}{c}\text { standard } \\
\text { deviation2 }\end{array}$ & \\
\hline Reading & 6.26 & 7.51 & 5.95 & 7.16 & 0.134 & Not sig. \\
\hline Writing & 2.31 & 2.58 & 1.42 & 1.32 & 1.385 & Not Sig. \\
\hline
\end{tabular}

$\mathrm{T}=2.42$ level 0,01

$\mathrm{T}=1,68$ level 0,05

It is clear from table (4) that there are no statistically significant differences between means of the children's scores of the experimental and control groups in the pre-test scale of reading and writing skills, which indicates the equivalence of the two groups.

\section{Research Hypotheses:}

\section{First Hypothesis:}

1- There are statistically significant differences between the mean of the experimental group children's scores and the mean of the control group children's scores in the post-test of using artificial intelligence applications to develop the reading and writing skills for kindergarten children with learning disabilities for the experimental group.

And to verify the validity of that hypothesis, the researcher has used the T-test to find the differences between the mean of the experimental group children' scores and the mean of the children's scores of the control group in the post-test after using artificial intelligence applications to develop the reading and 
writing skills for kindergarten children with learning disabilities on the scale of reading and writing skills in English as shown in a table (5).

\section{Table (5)}

Differences between the mean of children's scores of the experimental group and the mean of the children's score of the control group in the post-test after using artificial intelligence applications to develop the reading and writing skills for kindergarten children with learning disabilities on the scale of reading and writing skills in English

$$
\mathbf{N}=\mathbf{4 0}
$$

\begin{tabular}{|c|c|c|c|c|c|c|c||}
\hline \multirow{2}{*}{ Variables } & \multicolumn{2}{|c|}{ experimental group } & \multicolumn{2}{|c|}{ control group } & T & $\begin{array}{c}\text { Sig. } \\
\text { level }\end{array}$ & Sig. Direction \\
& $\begin{array}{c}\text { Mean } \\
\mathbf{N}=\mathbf{2 0}\end{array}$ & $\begin{array}{c}\text { standard } \\
\text { deviation1 }\end{array}$ & Mean2 & $\begin{array}{c}\text { standard } \\
\text { deviation2 }\end{array}$ & & & \\
\hline Reading & 44.31 & 3.26 & 8.16 & 6.9 & 18.64 & $\begin{array}{c}\text { Not } \\
\text { Sig. }\end{array}$ & $\begin{array}{c}\text { For } \\
\text { experimental } \\
\text { group }\end{array}$ \\
\hline Writing & 30.94 & 4.02 & 3.94 & 2.47 & 22.59 & $\begin{array}{c}\text { Not } \\
\text { Sig. }\end{array}$ & $\begin{array}{c}\text { For } \\
\text { experimental } \\
\text { group }\end{array}$ \\
\hline
\end{tabular}

$\mathrm{T}=2.35$ level 0,01

$\mathrm{T}=1,65$ level 0,05

It is clear from table (5) that there are statistically significant differences at the level of 0.01 between the mean of children's scores of the experimental and controlling groups in the post-test of after using artificial intelligence applications to develop the reading and writing skills for kindergarten children with learning disabilities on the scale of reading and writing skills of the experimental group. 


\section{Second hypothesis:}

There are statistically significant differences between the mean levels of children's grades in the pre and post scales after using artificial intelligence applications to develop the reading and writing skills for kindergarten children with learning disabilities for the post scale.

To verify the validity of this hypothesis, the researcher has used the Wilcoxon test to find the differences between the mean grade levels of children in the pre and post scales after using artificial intelligence applications to develop the reading and writing skills for kindergarten children with learning disabilities as shown in table (6).

\section{Table (6)}

Differences between The children's rank scores mean in the pre and post scales after the artificial intelligence applications to develop the reading and writing skills for kindergarten children with learning disabilities on the reading and writing skills scale

$$
\mathrm{N}=20
$$

\begin{tabular}{|c|c|c|c|c|c|c|c|}
\hline Variables & Pre \& post scale & No. & $\begin{array}{c}\text { Mean of } \\
\text { ranks }\end{array}$ & $\begin{array}{l}\text { Sum of } \\
\text { rank }\end{array}$ & $\mathbf{Z}$ & Sig. & $\begin{array}{c}\text { Sig. } \\
\text { direction }\end{array}$ \\
\hline Reading & $\begin{array}{l}\text { Negative rank } \\
\text { positive rank } \\
\text { equal rank } \\
\text { total }\end{array}$ & $\begin{array}{c}- \\
20 \\
- \\
20\end{array}$ & $\begin{array}{c}- \\
10.5\end{array}$ & $\begin{array}{c}- \\
210\end{array}$ & 3.923 & $\begin{array}{l}\text { Sig. level } \\
0.01\end{array}$ & $\begin{array}{l}\text { For post } \\
\text { scale }\end{array}$ \\
\hline Writing & $\begin{array}{l}\text { Negative rank } \\
\text { positive rank } \\
\text { equal rank } \\
\text { total }\end{array}$ & $\begin{array}{c}- \\
20 \\
- \\
20\end{array}$ & $\begin{array}{c}- \\
10.5\end{array}$ & $\begin{array}{c}- \\
210\end{array}$ & 3.935 & $\begin{array}{c}\text { Sig. level } \\
0.01\end{array}$ & $\begin{array}{c}\text { For post } \\
\text { scale }\end{array}$ \\
\hline
\end{tabular}

$\mathrm{Z}=2.58$ level 0.01

$\mathrm{Z}=1.96$ level 0.05

It is clear from table (6) that there are statistically significant differences at the level of 0.01 between the mean of children's scores of the experimental 
and controlling groups in the post-test of after using artificial intelligence applications to develop the reading and writing skills for kindergarten children with learning disabilities on the scale of reading and writing skills in the direction of the post scale.

The researcher also has found the percentage of improvement between the pre and post scales on the scale of reading and writing skills in the English language after the artificial intelligence applications as shown in table (7).

\section{Table (7)}

The percentage of improvement between the pre and post scales on the reading and writing skills scale after the artificial intelligence applications.

\begin{tabular}{|l|c|c|c|}
\hline Variables & $\begin{array}{c}\text { The mean of pre- } \\
\text { test }\end{array}$ & $\begin{array}{c}\text { The mean of } \\
\text { post-test }\end{array}$ & $\begin{array}{c}\text { Percentage of } \\
\text { development }\end{array}$ \\
\hline \hline Reading & 5.6 & 43.4 & $16.40 \%$ \\
\hline Writing & 0.58 & 30.3 & $8.9 \%$ \\
\hline
\end{tabular}

\section{The third hypothesis:}

There are statistically significant differences between the mean levels of children's grades in the pre and post scales after using artificial intelligence applications to develop the reading and writing skills for kindergarten children with learning disabilities on the reading and writing skills scale in the English language in the direction of follow-up scale.

To verify the validity of this hypothesis, the researcher has used the Wilcoxon test to find the differences between the mean grade levels of children in the post and following scales of the reading and writing skills after using 
artificial intelligence applications to develop the reading and writing skills for kindergarten children with learning disabilities as shown in table (8).

\section{Table (8)}

Differences between the children's rank scores mean in the post and following scales artificial intelligence applications to develop the reading and writing skills for kindergarten children with learning disabilities on the reading and writing skills scale

$$
\mathrm{N}=20
$$

\begin{tabular}{|c|c|c|c|c|c|c|c|}
\hline Variables & $\begin{array}{l}\text { Pre \& post } \\
\text { scale }\end{array}$ & No. & $\begin{array}{l}\text { Mean } \\
\text { rank }\end{array}$ & $\begin{array}{l}\text { Sum of } \\
\text { rank }\end{array}$ & $\mathbf{Z}$ & Sig. & $\begin{array}{c}\text { Sig. } \\
\text { Direction }\end{array}$ \\
\hline Reading & $\begin{array}{c}\text { Negative rank } \\
\text { positive rank } \\
\text { equal rank } \\
\text { total } \\
\end{array}$ & $\begin{array}{c}3 \\
- \\
17 \\
20 \\
\end{array}$ & $\begin{array}{l}2 \\
-\end{array}$ & $\begin{array}{l}6 \\
-\end{array}$ & 1.633 & Not sig. & - \\
\hline Writing & $\begin{array}{l}\text { Negative rank } \\
\text { positive rank } \\
\text { equal rank } \\
\text { total }\end{array}$ & $\begin{array}{c}12 \\
3 \\
5 \\
20\end{array}$ & $\begin{array}{l}8.04 \\
7.73\end{array}$ & $\begin{array}{l}96.5 \\
23.5\end{array}$ & 2.099 & $\begin{array}{c}\text { Sig. level } \\
0.05\end{array}$ & $\begin{array}{c}\text { For post } \\
\text { scale }\end{array}$ \\
\hline
\end{tabular}

$\mathrm{Z}=2.58$ level 0.01

$\mathrm{Z}=1.96$ level 0.05

It is clear from table (8) that there are statistically significant differences at the level of 0.01 between the mean of children's scores of the experimental and controlling groups in the post-test of after using artificial intelligence applications to develop the reading and writing skills for kindergarten children with learning disabilities on the following scale.

It is clear that there are no statistically significant Differences between The children's rank scores mean in the post and following scales after using artificial intelligence applications to develop the reading and writing skills for 
kindergarten children with learning disabilities on the reading and writing Skills scale.

\section{Conclusion:}

The deep integration of artificial intelligence and kindergarten children's education is a long-term, complex and difficult task. One of the most important aspirations of artificial intelligence was to understand human intelligence in all forms. The study results reveal the positive outcome, satisfactory usability and improved. Reading and writing skills development for kindergarten children with learning disabilities using artificial intelligence applications is necessary in these times.

\section{Recommendations:}

1- It is very significant to make usage of technology as a support to language development especially in two domains (reading and writing).

2- It is necessary to monitor the children and teach them how to use technology methods.

3- Support kindergarten classes with enough artificial intelligence applications.

4- Using artificial intelligence applications to develop reading and writing skills for kindergarten children with learning disabilities. 


\section{References:}

1- Bissaco, M. A. S., Frere, A. F., Bissaco, L. F., Manrique, A. L., Dirani, E., Rugerro, N., \& Amate, F. C. (2020). A computerized tool to assess reading skills of students with motor impairment. Medical Engineering \& Physics, 77, 31-42.

2- Bonneton-Botté, N., Fleury, S., Girard, N., Le Magadou, M., Cherbonnier, A., Renault, M. \& Jamet, E. (2020). Can tablet apps support the learning of handwriting? An investigation of learning outcomes in kindergarten classroom. Computers \& Education, 151, 103831.

3- Halilu, M., \& Ahmed, S. 2020. Overcoming Learning Disabilities among Children in Primary Schools, International Journal of Education and Evaluation. Vol 6. No. 2. PP 3-6.

4- Jin, L. (2019). Investigation on Potential Application of Artificial Intelligence in Preschool Children's Education. In Journal of Physics: Conference Series (Vol. 1288, No. 1, p. 012072). IOP Publishing.

5- Kamhi, A. G., \& Catts, H. W. (2002). The language basis of reading: Implications for classification and treatment of children with reading disabilities. Speaking, reading, and writing in children with language learning disabilities: New paradigms in research and practice, 45-72.

6- Khan, R. U., Cheng, J. L. A., \& Bee, O. Y. (2018). Machine Learning and Dyslexia: Diagnostic and Classification System (DCS) for Kids with Learning Disabilities. International Journal of Engineering \& Technology, 7(3.18), 97-100.

7- Liman, A. N., Adebisi, R. O., Jerry, J. E., \& Adewale, H. G. (2015). Efficacy of assistive technology on the educational programme of children with learning disabilities in inclusive classrooms of Plateau State Nigeria. Journal of Educational Policy and Entrepreneurial Research, 2(2), 23-32.

8- Lu, H., Zhang, K., \& Liu, Q. (2020). Reading fluency and pitch discrimination abilities in children with learning disabilities. Technology and Health Care, (Preprint), $1-10$.

9- Majed, R, Hatem, H \& Naser, A (2020). Blackboard systems based games for children with learning disabilities. International Research Journal of Computer Science (IRJCS). Issue 02, Volume 07.

10- Ouherrou, N., Elhammoumi, O., Benmarrakchi, F., \& El Kafi, J. (2019). Comparative study on emotions analysis from facial expressions in children with and without 
learning disabilities in virtual learning environment. Education and Information Technologies, 24(2), 1777-1792.

11-Pathak, N. (2017). Artificial Intelligence for. NET: Speech, Language, and Search: Building Smart Applications with Microsoft Cognitive Services APIs. Apress.

12-Prentzas, J. (2013). Artificial intelligence methods in early childhood education. In Artificial Intelligence, evolutionary computing and metaheuristics. pp. 169-199. Springer, Berlin, Heidelberg.

13-Rajapakse, S., Polwattage, D., Guruge, U., Jayathilaka, I., Edirisinghe, T., \& Thelijjagoda, S. (2018, December). ALEXZA: A Mobile Application for Dyslexics Utilizing Artificial Intelligence and Machine Learning Concepts. In 2018 3rd International Conference on Information Technology Research (ICITR) pp. 1-6. IEEE.

14-Richard, G., \& Serrurier, M. (2020). Dyslexia and Dysgraphia prediction: A new machine learning approach. ArXiv .Computer Science, Mathematics. Australia.

15- Taouil, M., Begdouri, A., \& Majda, A. (2018, October). Adaptive Dialogue System for Disabled Learners: Towards a Learning Disabilities Model. In 2018 IEEE 5th International Congress on Information Science and Technology (CiSt) pp. 422-427.

16-Tuomi, I. (2018). The impact of artificial intelligence on learning, teaching, and education. Luxembourg: Publications Office of the European Union.

17-Lu, H., Zhang, K., \& Liu, Q. (2020). Reading fluency and pitch discrimination abilities in children with learning disabilities. Technology and Health Care. pp 1-10.

\section{Arabic References:}

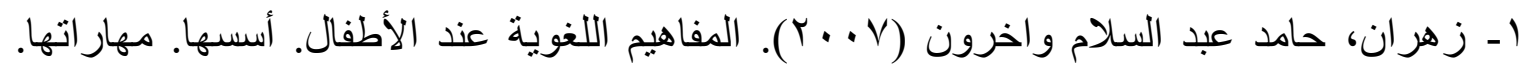

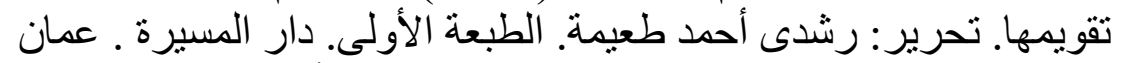

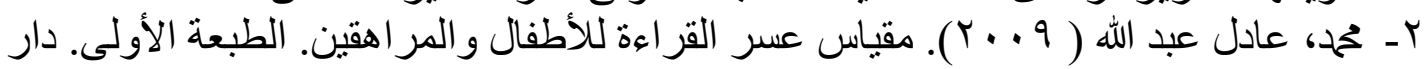

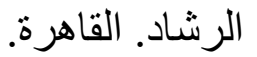
بـ الناثف، هدى محمود (9 (1 ب ). تتمية المهار ات اللغوية لأطفال ما قبل المدرسة.الطبعة الخامسة.

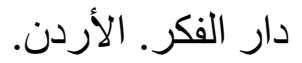

